\section{Postharvest Moisture Loss from Bare-root Roses Affects Performance of Containerized Plants}

\author{
Ursula K. Schuch ${ }^{1}$ \\ Plant Sciences Department, University of Arizona, Forbes Building, Room \\ 303, Tucson, AZ 85721
}

\section{H. Brent Pemberton}

Texas A\&M University Agricultural Research and Extension Center, P.O. Box 200, Overton, $T X 75684$

Jack J. Kelly

Pima County Cooperative Extension, 4210 North Campbell Avenue, Tucson, AZ 85719

Additional index words. postharvest handling, desiccation tolerance, transplanting, garden roses, Rosa, 'Angel Face', 'Blue Girl', 'First Prize', 'Mister Lincoln', 'Peace'

\begin{abstract}
Five cultivars of bare-root rose plants were exposed to increasing periods of drying and after rehydration were grown in containers until flowering in a plasticcovered greenhouse. At the start of the experiment, moisture content of well-hydrated roses was between $51 \%$ and $56 \%$. Five or $7 \mathrm{~h}$ of drying resulted in moisture contents below $43 \%$ for four of the cultivars and caused up to $80 \%$ mortality, increased time to flower, and decreased the number of flowering shoots. 'First Prize' was most tolerant of drying conditions and all plants survived, whereas 'Mister Lincoln' plants were most susceptible and had poor regrowth performance. Whole-plant moisture of 'Mister Lincoln' was similar to that in the stem or shank, which means that aboveground components instead of the entire plant can be used for moisture determination.
\end{abstract}

Deciduous plants that are field-grown in nurseries are generally dug when dormant in late fall, winter, and spring. Each year, several million dormant rose plants (Rosa L. sp.) are dug bare-root from production fields in California and Arizona and shipped immediately to other states where they are planted in containers and forced to flowering for nationwide marketing. Although precautions are taken, significant plant moisture loss has been observed to occur during digging, shipping, and potting operations.

Plant moisture loss during postharvest handling is considered one of the major causes of poor regrowth or failure to regrow (Insley and Buckley, 1985; Lefevre et al., 1991; McKay, 1997). Desiccation tolerance depends on growth stage and is greatest when plants are dormant (Coutts, 1981; Englert et al., 1993; Murakami et al., 1990; Ritchie and Roden, 1985). Bare-root seedlings of Pinus radiata D.Don plants are prone to greater moisture loss during storage than container seedlings, and after only 1-d storage at $4{ }^{\circ} \mathrm{C}$, reestablishment was significantly poorer compared with container seedlings (Mena-Petite et al., 2001). Packaged rose

Received for publication 31 Oct. 2006. Accepted for publication $25 \mathrm{Feb} .2007$.

We acknowledge the donation of rose plants from Bickman Farms, Litchfield Park, Ariz.

${ }^{1}$ To whom reprint requests should be addressed; e-mail ukschuch@ag.arizona.edu
1990). For norway maple (Acer platanoides L.) and washington hawthorn that lost $\approx 20 \%$ of their fresh weight, survival dropped to $40 \%$ and plant dieback increased to $90 \%$ (Englert et al., 1993). In contrast, red oak (Quercus rubra L.) lost water at a lower rate and at $18 \%$ moisture loss resulted in $95 \%$ survival and less than $40 \%$ dieback (Englert et al., 1993). All colorado spruce (Picea pungens glauca Engelm.) survived when seedlings lost up to $25 \%$ fresh weight during cold storage, but no seedlings survived when water loss was higher than $60 \%$ (Lefevre et al., 1991).

The objective of this study was to determine how postharvest moisture loss from field-grown bare-root plants in an arid climate affects subsequent growth and flowering performance of containerized garden roses in a nursery production setting.

\section{Materials and Methods}

Two-year-old rose plants were dug bareroot from a production field of a commercial nursery in Litchfield Park, Ariz., on 13 Feb. 2002. Within less than $60 \mathrm{~min}$ from uprooting, plants were taken into a warehouse area for wet storage, where plants were kept cool and freestanding moisture was maintained through frequent overhead mist. All plants had at least three canes that were at least $1 \mathrm{~cm}$ in diameter and $\approx 40 \mathrm{~cm}$ long. One day later, plants of rose cultivars 'Angel Face', 'Blue Girl', 'First Prize', 'Mister Lincoln', and 'Peace' were laid outdoors in the shade and protected from wind on a concrete loading dock and were allowed to air dry for $0,1,3,5$, or $7 \mathrm{~h}$. Wet and dry bulb temperatures were measured with a sling psychrometer; corresponding relative humidity conditions are shown in Table 1. Ten plants per cultivar and drying treatment were used in the study.

Fresh weight of plants was measured at the beginning and end of the assigned drying periods. Immediately after determining the fresh weight at the end of the drying period, plants were rehydrated by spraying them with tap water for $1 \mathrm{~min}$. Half of the plants were used for dry weight determination and the remaining half were forced into bloom to determine regrowth potential. Subsequently, five randomly selected plants per treatment and cultivar were wrapped in polyethylene, boxed in waxed cardboard boxes, and shipped the same day to Tucson, Ariz. 'Mister Lincoln' plants were dissected into canes, shank, and roots at the end of each drying time to determine if the different plant parts lose moisture at different rates. Plants were placed in a drying oven at $60^{\circ} \mathrm{C}$ for $10 \mathrm{~d}$, after which dry weights were determined. Moisture content in percent was calculated as (fresh weight - dry weight $) \times 100 /$ dry weight . Moisture content at the beginning of drying treatments was calculated to determine whether plants from each cultivar assigned to different drying periods had the same moisture content. Data presented are the moisture content at the end of each drying period.

The other five plants per treatment and cultivar were boxed in the same way and 
Table 1. Dry bulb, wet bulb, and relative humidity during desiccation of rose plants on $14 \mathrm{Feb}$. 2002.

\begin{tabular}{cccc}
\hline $\begin{array}{l}\text { Time } \\
\text { (HR) }\end{array}$ & $\begin{array}{c}\text { Dry bulb } \\
\left({ }^{\circ} \mathrm{C}\right)\end{array}$ & $\begin{array}{c}\text { Wet bulb } \\
\left({ }^{\circ} \mathrm{C}\right)\end{array}$ & $\begin{array}{c}\text { Humidity } \\
(\%)\end{array}$ \\
\hline $9: 00$ & 14.6 & 8.5 & 42 \\
$10: 30$ & 18.1 & 10.4 & 34 \\
$11: 30$ & 20.4 & 10.8 & 26 \\
$13: 00$ & 22.8 & 12.2 & 24 \\
$16: 00$ & 26.8 & 10.6 & 12 \\
\hline
\end{tabular}

were shipped in a refrigerated truck to a nursery in Tyler, Texas. They arrived within $48 \mathrm{~h}$ and still had freestanding moisture on all plant parts when unboxed. Care was taken to keep plants moist during potting. The canes were pruned to $15 \mathrm{~cm}$ and the plants were potted in no. $2(6.0 \mathrm{~L})$ nursery containers in a 80 bark: 20 sand mix (by volume) and were fertilized with $37.4 \mathrm{~g}$ per pot of slow-release fertilizer (Osmocote 19N-2.6P-10K; Scotts Co., Marysville, Ohio) and micronutrients. Plants were arranged in a completely randomized block design and grown in a clear plastic covered greenhouse with $31{ }^{\circ} \mathrm{C}$ day/ $12{ }^{\circ} \mathrm{C}$ night average temperatures until flowering. Plants were misted as needed until budbreak and then were overhead-irrigated as needed. As each plant flowered, the following variables were recorded: days from potting to flower, number of flowering and number of blind shoots (shoots ending growth without producing a flower), percent dieback, and a general performance rating. Performance was rated on a scale from 1 to 5 (worst to best) according to the following criteria: 1 = some leaves dead, short weak shoots, many blind shoots, and no flowers; 2 = short shoots with only one or two flowers, many blind shoots; 3 = vigorous shoots but few flowers, flowers usually from only one of the original canes, a few blind shoots, growth and vigor of growth from the original canes not uniform; 4 = vigorous shoots, more flowering than blind shoots, majority of the original canes producing flowering shoots, flowering not completely uniform; and $5=$ vigorous shoots, predominantly flowering shoots produced from all of the original canes, uniform shoots and flowers throughout the plant canopy.

\section{Results and Discussion}

Moisture loss and plant performance during forcing in containers. Moisture content of well-hydrated roses was between $51 \%$ and $56 \%$ (Fig. 1) and differed by cultivar and drying time over the course of the study. Seven hours of drying resulted in moisture contents of $43 \%$ or below for four of the cultivars. Moisture content of 'First Prize' was $56 \%$, highest among the cultivars at the beginning of drying time and remained highest at $45 \%$ at the end of drying (Fig. 1). Highest moisture loss between $4 \%$ to $6 \%$ was found for four cultivars during the first hour and is similar to other bare-root ornamentals (Murakami et al., 1990). Subsequent desic-

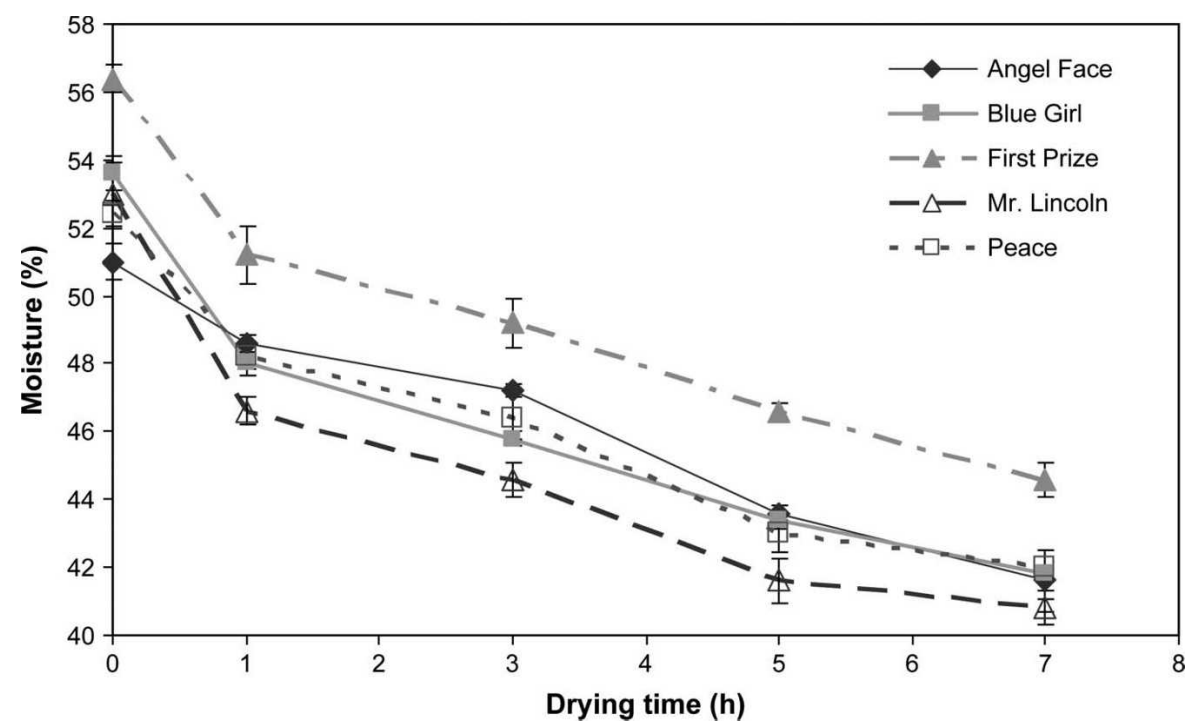

Fig. 1. Percent moisture of five cultivars of bare-root roses exposed to ambient outdoor conditions. Values are the means of five replications, error bars $=\mathrm{SE}$.

cation rates were $\approx 1 \%$ loss of moisture per hour. Moisture loss of 'Angel Face' was constant at a rate of $2 \%$ per hour during the study.

Number of flowering shoots from forced roses was affected by an interaction between cultivar and drying time (Fig. 2). 'Angel Face' produced the greatest number of flowers and 'Mister Lincoln' the least. Decreasing moisture concentration reduced the amounts of flowering shoots produced by all cultivars. All cultivars with the exception of 'Mister Lincoln' produced some flowering shoots even at the lowest moisture content after $7 \mathrm{~h}$ at ambient conditions.

The onset of vegetative growth when leaves were unfolding was delayed 11 to 18 d compared with plants not exposed to drying

conditions; however, the extent of delay varied by cultivar (Table 2). Response of 'Mister Lincoln' could not be characterized by a linear, quadratic, or cubic regression, because this late-to-leaf-out cultivar showed only a delay in resuming growth when exposed to drying for $5 \mathrm{~h}$. Dieback of rose plants ranged from $8 \%$ to $26 \%$ for plants not exposed to drying up to $88 \%$ for plants drying for $7 \mathrm{~h}$ (Table 2). Dieback varied by cultivar and drying time and was lowest with a maximum of $29 \%$ in 'First Prize', whereas all other cultivars suffered $65 \%$ or greater dieback of canes for at least one treatment.

Moisture content below $43 \%$ resulted in a sharp increase in plant mortality (Fig. 3). A previous study of containerized roses found

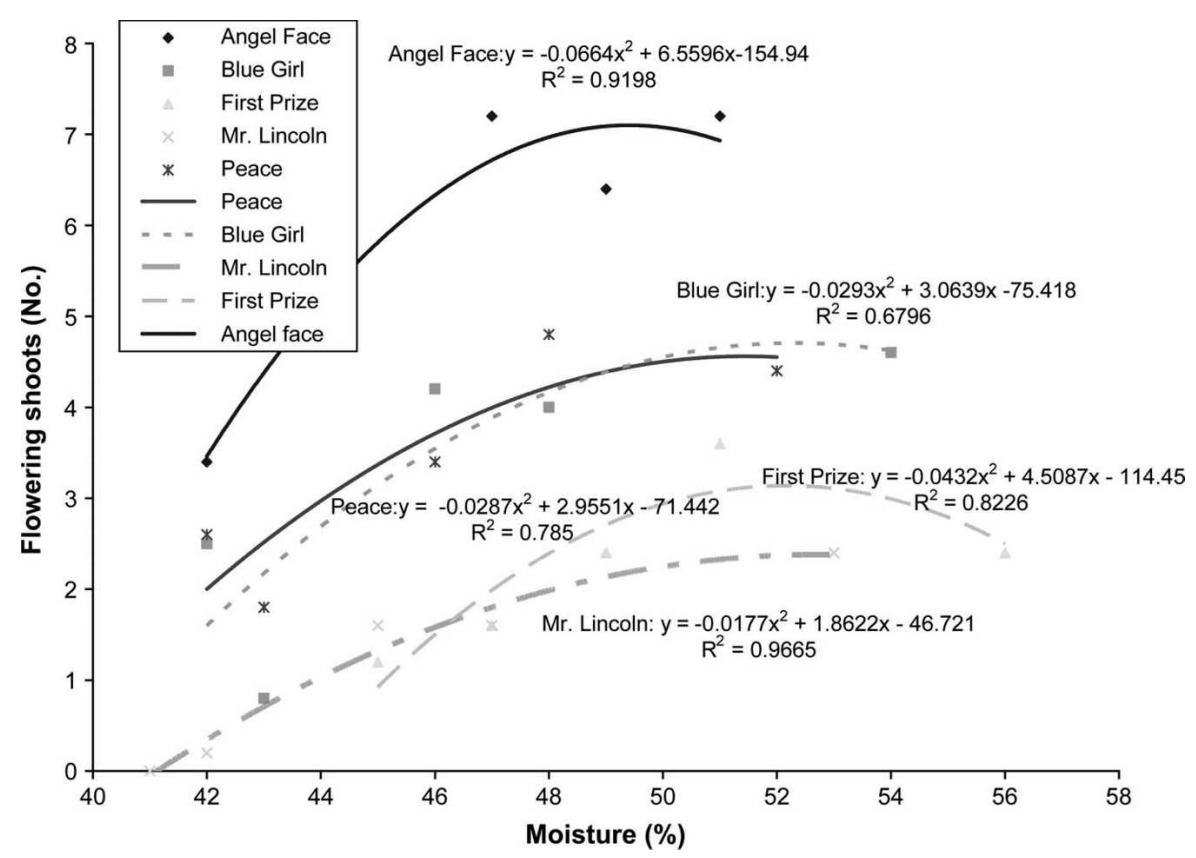

Fig. 2. Number of flowering shoots of five cultivars of bare-root roses that were forced after postharvest drying to different tissue moisture content before rehydration. 
Table 2. Effect of cultivar and drying time on growth of potted bare-root roses. ${ }^{\mathrm{z}}$

\begin{tabular}{|c|c|c|c|}
\hline Cultivar & $\begin{array}{l}\text { Drying } \\
\text { time }(\mathrm{h})\end{array}$ & $\begin{array}{l}\text { Days to leaf } \\
\text { unfolding }\end{array}$ & $\begin{array}{c}\text { Dieback } \\
(\%)\end{array}$ \\
\hline \multirow[t]{6}{*}{ Angel Face } & 0 & 31 & 15 \\
\hline & 1 & 35 & 10 \\
\hline & 3 & 47 & 14 \\
\hline & 5 & 47 & 17 \\
\hline & 7 & 41 & 65 \\
\hline & & $\mathrm{L}, \mathrm{C}^{\mathrm{y}}$ & - \\
\hline \multirow[t]{6}{*}{ Blue Girl } & 0 & 33 & 8 \\
\hline & 1 & 39 & 14 \\
\hline & 3 & 40 & 10 \\
\hline & 5 & 41 & 86 \\
\hline & 7 & 48 & 27 \\
\hline & & $\mathrm{L}$ & 一 \\
\hline \multirow[t]{6}{*}{ First Prize } & 0 & 30 & 12 \\
\hline & 1 & 42 & 20 \\
\hline & 3 & 43 & 29 \\
\hline & 5 & 44 & 26 \\
\hline & 7 & 40 & 29 \\
\hline & & Q & - \\
\hline \multirow[t]{6}{*}{ Mister Lincoln } & 0 & 42 & 18 \\
\hline & 1 & 42 & 36 \\
\hline & 3 & 44 & 40 \\
\hline & 5 & 53 & 83 \\
\hline & 7 & 41 & 88 \\
\hline & & - & - \\
\hline \multirow[t]{6}{*}{ Peace } & 0 & 37 & 26 \\
\hline & 1 & 42 & 27 \\
\hline & 3 & 41 & 14 \\
\hline & 5 & 55 & 74 \\
\hline & 7 & 49 & 24 \\
\hline & & $\mathrm{L}, \mathrm{C}$ & - \\
\hline \multicolumn{4}{|c|}{ Analysis of variance } \\
\hline Cultivar (CV) & & $*$ & $* *$ \\
\hline $\begin{array}{l}\text { Drying } \\
\quad \text { time (DT) }\end{array}$ & & $* *$ & $* *$ \\
\hline $\mathrm{CV} \times \mathrm{DT}$ & & $*$ & $* *$ \\
\hline
\end{tabular}

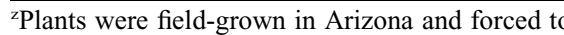
bloom in containers in Texas.

ySignificant regression coefficients: $\mathrm{L}=$ linear, $\mathrm{Q}=$ quadratic, $\mathrm{C}=$ cubic.

,*** Significant at $P \leq 0.05$ and 0.01 , respectively.

that moisture content between $33 \%$ and $41 \%$ was critical for survival (Pemberton and Roberson, 1990). Also, packaged plants with moisture content between $28 \%$ and $43 \%$ resulted in reduced new growth and greater mortality for some cultivars after field planting when compared with packaged rose plants with plant moisture of $\approx 50 \%$ (Welch and Cameron, 1990).

In both studies, the rate of drying was much lower than in our study reported here. Loss of $1 \%$ or less moisture per hour was reported by Pemberton and Roberson (1990) and a much lower rate of drying over a period of 4 weeks of simulated marketing where roots were packaged (Welch and Cameron, 1990). A slower rate of moisture loss from dormant plants improved survival of red oak compared with the faster loss of moisture in norway maple and washington hawthorn (Englert et al., 1993). Accounting for species and cultivar differences, these results suggest that $43 \%$ is a critical threshold for survival and successful regrowth regardless of the rate of moisture loss. This makes protecting bareroot plants from moisture loss in an arid climate especially important, because drying rates can be high and the critical moisture threshold can be reached very quickly.

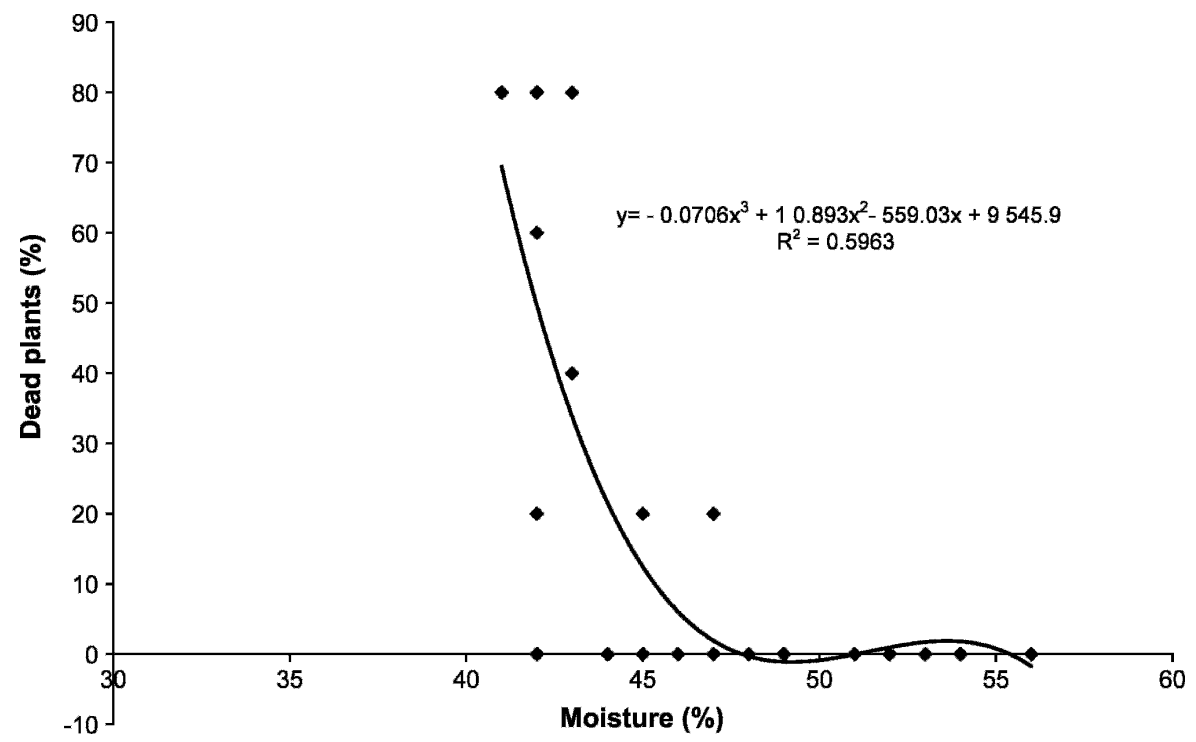

Fig. 3. Relationship between plant moisture percent before rehydration and percentage of dead plants during forcing containerized bare-root roses. Each value is the mean of five observations and data from five cultivars are included.

The number of days to flowering and performance rating were affected by cultivar and drying time (Table 3). 'Angel Face' and 'Blue Girl' flowered first, 116 and 118 d after potting, respectively, whereas 'Mister Lincoln' started blooming last, after 123 d. Drying time increased the time to bloom linearly from $116 \mathrm{~d}$ for control plants to $122 \mathrm{~d}$. Performance rating of 'Mister Lincoln' was lowest at 1.9 , which was incited by both the high rate of mortality and the poor performance of plants at drying times as low as 1 and $3 \mathrm{~h}$. 'Angel Face', 'Blue Girl', and 'Peace' had the highest performance ratings, ranging from 3.1 to 2.7 , respectively. Increasing drying time linearly reduced performance rating from 3.2 to 2.0 when data were pooled over all cultivars. Previous studies reported delayed onset of flowering, fewer flowers, and overall poorer performance of roses exposed to desiccating conditions before field planting (Pemberton and Roberson, 1990; Schuch et al., 1995; Welch and Cameron, 1990). This study shows that moisture loss resulting in plant moisture content below $43 \%$ has a negative effect on rose plants forced in containers as well.

Moisture loss of individual parts of 'Mister Lincoln'. Root, stem, and shank moisture content of 'Mister Lincoln' roses were similar before exposure to ambient conditions (Fig. 4). The greatest rate of moisture loss for each component was highest during the first hour. Stem, shank, and whole plants lost moisture at a similar rate during the remainder of the study, whereas roots desiccated at a faster rate in the second half of the study. Greater moisture loss of roots is likely a result of the greater surface area and the lack of a thicker cuticle, which makes this tissue more susceptible to desiccation compared with the other plant parts. Ambient conditions likely hastened the drying process of susceptible tissue during the
Table 3. Days to flowering and performance rating of potted bare-root roses. ${ }^{z}$

\begin{tabular}{lcc}
\hline Cultivar & $\begin{array}{c}\text { Days to } \\
\text { flower }\end{array}$ & $\begin{array}{c}\text { Performance } \\
\text { rating }^{\mathrm{x}}\end{array}$ \\
\hline Angel Face & $116 \mathrm{a}^{\mathrm{y}}$ & $3.1 \mathrm{a}$ \\
Blue Girl & $118 \mathrm{a}$ & $3.0 \mathrm{a}$ \\
First Prize & $119 \mathrm{ab}$ & $2.4 \mathrm{ab}$ \\
Mister Lincoln & $123 \mathrm{~b}$ & $1.9 \mathrm{~b}$ \\
Peace & $120 \mathrm{ab}$ & $2.7 \mathrm{a}$ \\
Drying time (h) & & \\
0 & $116 \mathrm{~b}$ & $3.2 \mathrm{a}$ \\
1 & $119 \mathrm{ab}$ & $3.1 \mathrm{a}$ \\
3 & $119 \mathrm{ab}$ & $2.8 \mathrm{a}$ \\
5 & $122 \mathrm{a}$ & $2.0 \mathrm{~b}$ \\
7 & $120 \mathrm{ab}$ & $2.0 \mathrm{~b}$ \\
& $\mathrm{~L}^{\mathrm{w}}$ & $\mathrm{L}$ \\
\hline
\end{tabular}

${ }^{2}$ Plants were field-grown in Arizona and containerforced in Texas. Means for cultivar are pooled over drying time and drying time means are pooled over cultivar.

${ }^{\mathrm{y}}$ Means followed by different letters within a column are different at $P<0.05$, means separation by Tukey's studentized test.

${ }^{x}$ Rating scale $1-5$, worst to best.

${ }^{\text {w}}$ Significant linear regression coefficient.

last $3 \mathrm{~h}$ of the experiment when relative humidity dropped from $24 \%$ to $12 \%$ (Table 1). Previous studies reported that roots of washington hawthorn and norway maple lost water at a faster rate than shoots, $18 \%$ of water loss in roots versus $3 \%$ to $4 \%$ in shoots after $10 \mathrm{~h}$ (Englert et al., 1993). Root systems with greater surface area-to-volume ratio were speculated to contribute to the greater desiccation tolerance of Fraxinus angustifolia Vahl., with a coarser root system, versus Betula pubescens, which has a finer root system (Insley and Buckley, 1985).

Based on our results, whole-plant moisture content can be determined accurately using only aboveground components of rose plants. Although roots desiccated at a faster rate and overall had a lower moisture content after $7 \mathrm{~h}$ of exposure to ambient conditions, 


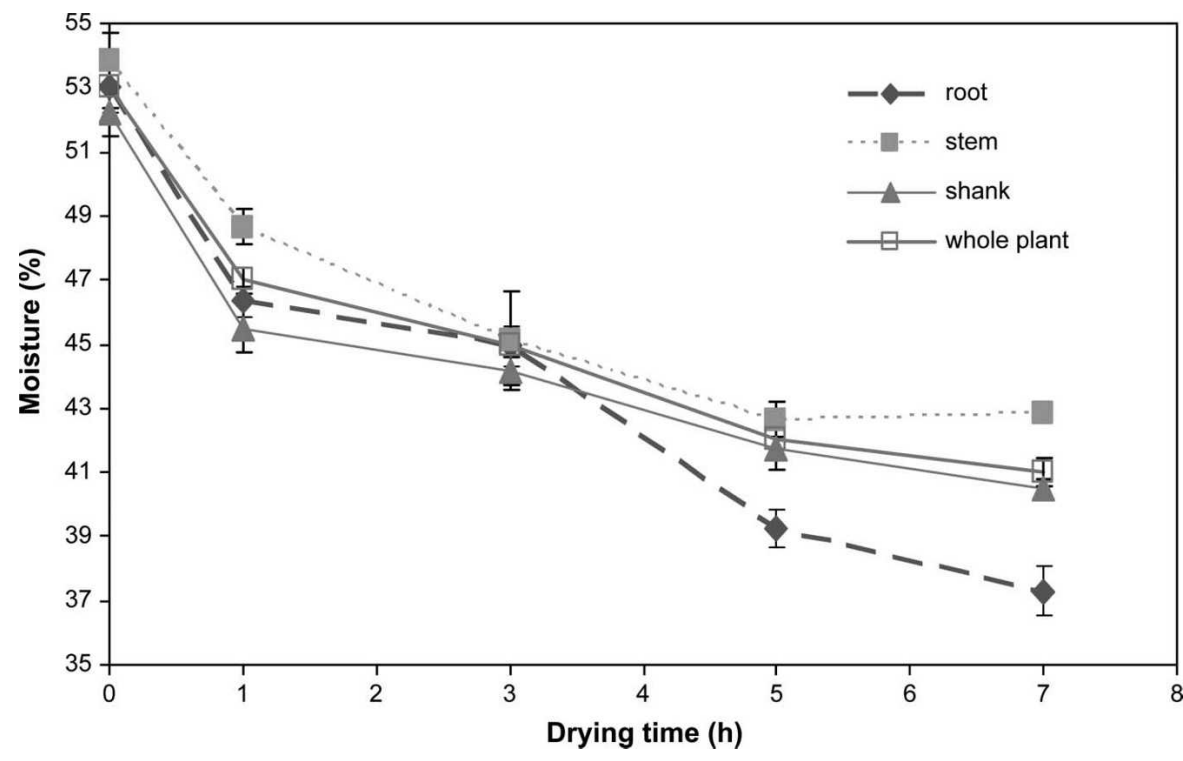

Fig. 4. Percent moisture of roots, stems, shanks, and whole plants of 'Mister Lincoln' bare-root roses exposed to ambient outdoor conditions for $7 \mathrm{~h}$. Values are the means of five replications, error bars $=\mathrm{SE}$.

their small contribution to the total weight of plants makes them less critical for moisture content determination.

In conclusion, the moisture loss of bareroot rose plants exposed to ambient conditions in an arid climate led to slower onset of vegetative growth and flowering, reduced number of flowering shoots, greater dieback of canes, and lower overall performance rating than plants that were not exposed to desiccation. Tolerance to desiccation differed between the five cultivars of garden roses tested, but moisture content below 43\% before shipping plants from the production nursery resulted in up to $80 \%$ dead plants and cane dieback. Moisture loss of whole plants during drying conditions was similar to those of either canes or the shank, and therefore moisture content of aboveground parts of roses can be considered representative of
Englert, J.M., K. Warren, L.H. Fuchigami, and T.H.H. Chen. 1993. Antidesiccant compounds improve the survival of bare-root deciduous nursery trees. J. Amer. Soc. Hort. Sci. 118:228235.

Insley, H. and G.P. Buckley. 1985. The influence of desiccation and root pruning on the survival and growth of broad-leaved seedlings. J. Hort. Sci. 60:377-387.

Lefevre, R.E., A.C. Cameron, and N.C. Peterson 1991. Influence of moisture loss during storage on new growth of conifer seedlings. J. Environ. Hort. 9:92-96.

McKay, H.M. 1997. A review of the effect of stresses between lifting and planting on nursery stock quality and performance. New For. 13:369-399.

Mena-Petite, A., U. Ortega-Lasuen, M.B. GonzálezMoro, M. Lacuesta, and A. Muñoz-Rueda. 2001. Storage duration and temperature effect on the functional integrity of container and bare-root Pinus raidata D. Don stock-types. Trees (Berl.) 15:289-296.

Murakami, P., T.H.H. Chen, and L.H. Fuchigami. 1990. Desiccation tolerance of deciduous plants during postharvest handling. J. Environ. Hort. 8:22-25.

Pemberton, H.B. and W.E. Roberson. 1990. Critical tissue moisture levels needed for maintenance of rose plant viability. HortScience 25:863. Abstr.

the whole plant. The rose industry needs to be sensitive to the issue of rose plant moisture loss. If water is not available in the field during digging (especially on warm, windy, dry days), tarps should be used to cover plants during transport to storage facilities. Also, plants should not be left exposed on shipping docks or in planting areas during breaks and especially overnight without providing a means to keep the plant surfaces constantly moist.

\section{Literature Cited}

Bates, R.M. and A.X. Niemiera. 1994. Mist irrigation reduces post-transplant desiccation of bare-root trees. J. Environ. Hort. 12:1-3.

Coutts, M.P. 1981. Effects of root or shoot exposure before planting on the water relations, growth, and survival of sitka spruce. Can. J. For. Res. 11:703-709.
Rebhuhn, M.K. 1985. Characterization of harvestable maturity development in roses. Oregon State University, Corvallis, MS Thesis.

Ritchie, G.A. and J.R. Roden. 1985. Physiological quality of lodgepole pine and interior spruce seedlings: Effects of lift date and duration of freezer storage. Can. J. For. Res. 15:636645.

Schuch, U.K., J.F. Karlik, and C. Harwood. 1995. Antidesiccants applied to packaged rose plants affect growth and field performance. HortScience 30:106-108

Toy, S.J. and J.P. Mahlstede. 1959. The effect of paraffining, pruning, and other storage treatments upon the growth of roses and cherry trees. Proc. Amer. Soc. Hort. Sci. 28:489-495.

Welch, C.K. and A.C. Cameron. 1990. Elevated temperatures during simulated marketing reduce field performance of packaged rose bushes. HortScience 25:677-679. 